\title{
The Effects of Blended Learning with Social Media on Smart Phone to Enhance Critical Thinking of Junior High School
}

\author{
Tossabhorn Saengchampi ${ }^{1+}$ and Tawee Sranamkam ${ }^{2+}$ \\ ${ }^{1}$ Master in Educational Technology, Faculty of Education, Khon Kaen University, Thailand \\ ${ }^{2}$ Assistant Professor, Educational Technology, Faculty of Education, Khon Kaen University, Thailand
}

\begin{abstract}
This research has purpose. 1) To develop a Blended Learn ing with social media on Smart Phone to enhance critical thinking for junior high school students 2) To compare the critical thinking of the students who study with a blended learning. 3) To compare the achievement of students who study with the blended learning. Sample were 32 students of Junior High School, Ban Nawer Non-Udom School, and Bueng Kan Primary Educational Service Area Office, enrolled in the first semester of the academic year 2018 by simple random sampling. The instruments of this research were 1) a blended learning, which the efficiency of $81.25 / 80.63$ 2) a test of critical thinking entitle "Computer in daily" 3) a test of achieve ment entitle "Computer in daily". Research methodology; a one group pretest and posttest. Data analy zed with t-test. The results of this research were as follows. 1) The Blended Learning have the efficiency of 81.25/80.63 2) The Critical thinking after learning with blended learning was higher than before learning at a significance level .05. 3) The learning achievement of students after learning by using blended learning was higher than before learning at a significance level .05
\end{abstract}

Keywords: Blended Learning, Smart Phone, Social Media, Critical Thinking, Achievement.

\section{Introduction}

Current advances in technology (IT) that cause new ways to store data, information, and news. Knowledge transmission through communication, information access, information received, including the creation of Social Informatics and information technology industry and in managing information effectively and in accordance with the implemented in everyday life perfectly. Again, both are critical for organizations to help facilitate operations. Make the data access speed. Communication with efficiency and save costs in the operation of the work unit in the system, such as the Internet connection to send and receive electronic mail. The website is for promotional tools.

The Basic Education Core Curriculum 2008 thus formulated will provide local communities and schools with a framework and orientation for preparing school curriculums. Teaching-learning activities organised for all Thai children and youths at basic education level are aimed at enhancing learners' quality regarding essential knowledge and skills required for their lives in an ever-changing society. They will thus be empowered to seek further knowledge for continuous lifelong self-development. (Core curriculum, 2008) [1]

Blended learning is any time a student learns at least in part at a supervised brick- and-mortar location away from home and at least in part through online delivery with some element of student control over time, place, path, and/or pace [2], Blended learning is integration or a blend between face-to-face instruction and online instruction.[3]

There are many different approaches to subcategorizing thinking processes. For example, in Bloom's Taxonomy the cognitive doma in is categorized into knowledge, comprehen- sion, application, analys is,

\footnotetext{
${ }^{+}$Corresponding author.

E-mail address: bankcoms@ gmail.com ${ }^{1}$, tawsra@ gmail.com ${ }^{2}$.
} 
synthesis and evaluation (Bloom et al., 1956). Shiever (1991) and Baker and Baker (1994) Weinstein (2000) pro- poses a framework of critical thinking that includes: 1) skillful thinking; 2) responsible thinking; 3) nonroutine thinking; 4) applying criteria; 5) self-correction; 6) sensitivity. According to Ennis (1987) [4]

From such a reason. Students would study the creation of an integrated lesson that relies on basic critical thinking with leading social media., Which focuses on teaching by critical thinking, that applied to teaching and learning on the Internet network is to bring computer technology. Learn management techniques and technologies to communicate over the network to the application Internet access. The result of a blend of lessons, integrating social media, this is the approach that will lead to the development of the blended learning with social media on smart phone to enhance critical thinking of junior high school, learning through the Internet are contained in the developmental teaching and teaching materials effectively. Students can take to maximize the educational reforms that focus on students is important. By aim will be the guide lines that help people learn happily. I think there are besides a higher quality and nay an as destination of the next course.

\section{Objectives}

2.1 to develop Blended Learning with Social Media on Smart Phone to Enhance Critical Thinking of Junior High School.

2.2 to compare the critical thinking in students taught by Blended Learning with Social Media on Smart Phone.

2.3 to compare learning achievement between before and after learning by Blended Learning with Social Media on Smart Phone.

\section{Methodology}

\subsection{Population and sample}

Sample in this research were 32 students of Junior High School, Ban Nawer Non-Udom School, Bueng Kan Primary Educational Service Area Office, North East of Thailand, which enrolled in the first semester of the academic year 2018 by using simple random sampling.

\subsection{Instruments}

3.2.1 Tools used in the experiments. Blended learning with social media on smart phone to enhance critical thinking of junior high school students at URL: www.krubanked.com

3.2.2 using the tools in the data collected in this research include: 1) measure critical thinking before and after classes. There is a difficulty value is between $0.50-0.80$ value power classification is between $0.20-0.60$ charge conviction of the entire test, equivalent to 0.94 [4] 2) The learning achievement evaluation 20 multiple choice question for pre-test and post-test. Questions were created based on revised Bloom' taxonomy [5] having difficulty lies between 0.40 to 0.20 to 0.75 comprises value between 0.80 charge conviction of the entire test, equal to 0.89 .

\subsection{Data collection}

Researchers have created a blended learning and research results of a blend of lessons, integrating social media on your Smartphone to promote critical thinking. For students attending secondary school at the beginning of the performance and analysis the lessons and results of research, integrated use of procedures and processes. The following.

3.3.1 Study research papers related to teaching and learning through the Internet to a preliminary finding teaching format on the Web, this procedure is the appropriate data gathering by research papers and research database.

3.3.2 Theoretical study of critical thinking.

3.3.3 Course textbook in related documents in the content. The story, computer in everyday life, which was content in this blended learning.

3.3.4 Define behavioral objectives, in line with most content and Create table test analysis. 
3.3.5 Create lessons blended learning by using the program LMS Moodle as Web page design and Using program Adobe Photoshop incoming image decoration.

3.3.6 Create a measure of critical thinking.

3.3.7 Quiz created and modified take it to experts.

3.3.8 Check out the performance of the blended learning in 1) One to one testing 2) Small group testing and 3) Field testing

3.3.9 Scores of practice all 4-modules and test score, after learning from the research sample groups of students came to the performance analysis of integrated lessons E1/E2 demonstrates that integrated lessons that build up effective and can used to support as a teaching media in the classroom and online learning.

\section{Conclusion}

4.1. The results of the performance in blended learning.

Table 1 Show step of testing for calculate the effectiveness of the blended learning.

\begin{tabular}{|c|c|c|c|c|}
\hline The experiments & $\begin{array}{c}\text { The number } \\
\text { of groups. } \\
\text { (Group) } \\
\text { (member) }\end{array}$ & $\begin{array}{c}\text { Total score: } \\
\text { activity } \\
(\mathbf{1 0 0})\end{array}$ & $\begin{array}{c}\text { The score after } \\
\text { each examination. } \\
\mathbf{( 4 0 )}\end{array}$ & $\begin{array}{c}\text { The effectiveness } \\
\text { of the Blended } \\
\text { Learning } \\
\left(\mathbf{E}_{\mathbf{1}} / \mathbf{E}_{\mathbf{2}}\right)\end{array}$ \\
\hline One to One Testing & $1(4)$ & 285 & 118 & $71.25 / 73.75$ \\
\hline Small Group Testing & $2(8)$ & 589 & 243 & $73.63 / 75.94$ \\
\hline Field Testing & $5(20)$ & 1625 & 645 & $\mathbf{8 1 . 2 5 / 8 0 . 6 3}$ \\
\hline
\end{tabular}

From Table 1 shows that one-to-one study, the researcher has the efficiency value (E1 / E2) equal to $71.25 / 73.75$. The small group study has the efficiency value (E1 / E2) equal to $73.63 / 75.94$. The field has the efficiency value (E1 / E2) equal to $81.25 / 80.63$.

A summary of studies to find out the effectiveness of integrated social media integration to promote critical thinking for middle school students. An effective (E1/E2) equal to 81.25/80.63, which meets the criteria set is $80 / 80$ can use the instruction. Mathematics, computer and information technologies, promote critical thinking. For middle school students

\subsection{The results of the comparing on Critical Thinking}

Table 2 Shows a table to compare the scores of critical thinking before the study after study.

\begin{tabular}{|l|c|c|c|c|c|}
\hline \multicolumn{1}{|c|}{ Experimental group } & $\begin{array}{c}\text { The number of } \\
\text { groups } \\
\text { (people) }\end{array}$ & $\overline{\mathbf{X}}$ & S.D. & T & P \\
\cline { 1 - 3 } $\begin{array}{l}\text { Points of critical thinking } \\
\text { before blended learning }\end{array}$ & 32 & 12.72 & 2.57 & \multirow{2}{*}{-3.315} & \multirow{2}{*}{$.000 *$} \\
\cline { 1 - 3 } $\begin{array}{l}\text { Points of critical thinking after } \\
\text { blended learning }\end{array}$ & 32 & 17.00 & 1.19 & \\
\hline
\end{tabular}

$* \mathrm{p}<.05, \mathrm{df}=31$

From Table 2 Found that critical thinking score, before studying. Average rating is equal to the standard deviation equal to 12.722 .57 points to measure critical thinking school. Average score of 17.00 worth deviation equal to 1.19 and t-test value equal to-it appears that results from 3.315 critical thinking before the higher classes after learning that statistically significant outage .05

\subsection{The results of the comparing on Achievement}

Table 3 Show a table to compare the scores to achievement before the study after study.

\begin{tabular}{|l|c|c|c|c|c|}
\hline \multicolumn{1}{|c|}{ Experimental group. } & $\begin{array}{c}\text { The number } \\
\text { of groups } \\
\text { (people) }\end{array}$ & $\overline{\mathbf{X}}$ & S.D. & T & P \\
\hline $\begin{array}{l}\text { Achievement scores } \\
\text { before blended learning }\end{array}$ & 32 & 13.16 & 2.42 & \multirow{2}{*}{-3.392} & $.000^{*}$ \\
\cline { 1 - 4 } $\begin{array}{l}\text { Achievement scores } \\
\text { after blended learning }\end{array}$ & 32 & 17.50 & 1.31 & \\
\hline
\end{tabular}

$* \mathrm{p}<.05, \mathrm{df}=-3.392$ 
From table 3, found that the scores to measure achievement. Average rating is equal to the standard deviation equals to 13.162 .42 points to measure school achievement. Average rating is equal to 17.50 worth deviation equal to 1.19 and t-test value equal to-it appears that results from 3.392 measuring achievement before the higher classes after learning that statistically significant outage .05

\section{Discussion}

5.1 The result of the performance of the blended learning with social media on smart phone to enhance critical thinking Of junior high school E1/E2 performance values are equal to the defined criteria is met, namely, 80/80.

5.2 Towards critical thinking in blended learning with social media on smart phone to enhance critical thinking Of junior high school There are scores of examples with respect to inscribe the mystics after higher than before the study statistically significant at the level .05

5.3 The Learning achievement with the result achievement after higher than before the study statistically significant at the level .05

\section{Suggestions}

\subsection{Suggestions from this research}

6.1.1 The lessons can apply in the management of teaching and learning in mathematics and computer technology, material, collected in development knowledge and critical thinking skills to develop skills to think, sometimes with higher balances of worship.

6.1.2 The lessons can use as a guide line for the integration to adjust application to manage learning and computer technology, as well as other courses, instructors can be applied appropriately.

6.1.3 Should find a way to motivate students to participate in the comments to use chat rooms to create the interaction of participants learn to maximize the excitement in learning more.

6.1.4 Using the mixed use of the lesson how to learn other users should use high speed Internet for continuity and a seamless image.

\subsection{Suggestions to study next research}

6.2.1 Should create a blend of lessons in the other strand other classes vary in order to research the effects of integrated management in teaching.

6.2.2 Should research and dealing with other forms of teaching and learning by using a variety of blending lessons, and use other formats.

6.2.3 The aspect ratio should use on a blended learning, teaching online and face-to-face in different ratios, such as 60:40 or 50:50 etc.

\section{Acknowledgment}

Research Fund 2019 of Graduate School and Faculty of Education, Khon Kaen University, Thailand supported support research. In addition, a special thanks to all of the Junior high school students, Bueng kan, North East, Thailand. Samples to devote valuable time for blended learning and testing in this research.

\section{References}

[1] The Basic Education Core Curriculum B.E. 2551 (A.D. 2008)

[2] Horn, M.B., \& Staker, H. (2011). The Rise of K-12 Blended Learning. USA: Innosight Institute.

[3] Bonk, C.J., \& Graham, C.R. (Eds.). [n.d.]. Handbook of blended learning: Global Perspectives, local designs. San Francisco, CA: Pfeiffer Publishing.

[4] Facione, P.A. (1990). Critical Thinking: A Statement of Expert Consensus for Purposes of Educational Assessment and Instruction. Retrieved June 1, 2006.

[5] Anderson,L.W., \& Krathwohl, D.R. (2001). A taxonomy for learning, teaching, and assessing: A revision of Bloom's taxonomy of educational objectives. New York: Addison Wesley Longman. 